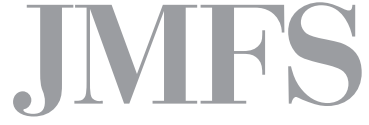

Journal of Management and Financial Sciences
Volume XI

Issue 34 (November 2018)

pp. 93-101

Warsaw School of Economics

Collegium of Management and Finance

Marta Ziółkowska

Collegium of Management and Finance

SGH Warsaw School of Economics

\title{
Determinants of choosing a business model in small and medium-sized enterprises
}

\begin{abstract}
In the face of continuous changes in the business environment both in local markets and worldwide, we need adequate elements of a business model that would allow enterprises to compete and help them generate market value. The paper conceptualises the notion of a business model and the role it plays in small and medium-sized enterprises (SME); it also examines determinants of choosing the right business model. It conceptualises the term and subject of business model analysis. The discussion of determinants of choosing the right business model in SMEs is preceded with an overview of literature and desk research analysis which demonstrate the need to systematically investigate the issue.
\end{abstract}

Keywords: small and medium-sized enterprises, business model, determinants of enterprise growth JEL Classification Codes: L 250 


\section{Introduction}

Contemporary circumstances in the business environment call for seeking factors which will help business organisations to become highly efficient. Previously applied solutions were largely based on the mastering of business processes and the conduct of enterprises. In the face of continuous changes in the business environment, both in local markets and worldwide, we need adequate elements of a business model that would allow enterprises to compete and help them generate market value. An overview of literature in management science lets us conclude that so far little attention has been paid to determinants of choosing the right business model in the management practice of small and medium-sized enterprises (SME). A research gap has emerged in relation to the revision of the understanding of a business model in the SME sector, which should offer value higher than that offered by one's competitors and enhance the market value of a company. An adequate business model ensures strategic preparedness, which helps create value.

This paper aims at conceptualising the notion of a business model and the role it plays in small and medium-sized enterprises in analysing the determinants of choosing the right business model. Conclusions have been drawn using desk research methodology.

\section{Business model: its notion and concept in small and medium-sized enterprises}

The term "business model" targets the foundations of economic activity and it describes how business runs. It consists of two components. A model is a structure, a scheme that tells us how a particular phenomenon or object works, how it is built and what are its features. It can also be described as a simplified reflection of reality [Sławińska, 2010, p. 9]. Business, in turn, is an economic activity - whose type is decided by the needs of its customers - pursued continuously and in an organised way in return for money. By combining the above two terms in one definition, a business model has been explained in the literature as a set of elements and relationships among them, which serve business logic of an enterprise. A business model is a compilation of values offered by an enterprise to one or several segments of customers as well as an organisational scheme of its architecture and network of relations with partners, which ensures revenue leading to profitability of the business in question [Osterwalder et al., 2005, p. 10]. The plethora of business model interpretations in the subject matter literature generates interpretation problems connected with correct understanding of the term and its role in key management concepts. A business model as a simplification of complex reality helps identify business foundations and plan its evolution. The term "business model" represents principal assumptions of economic activity and the operational logic, a model that 
defines how activities are pursued. It is a collection of fundamental building blocks, such as: resources, internal and external relations and causal relationships among them (see Figure 1).

Figure 1. Substance of a business model

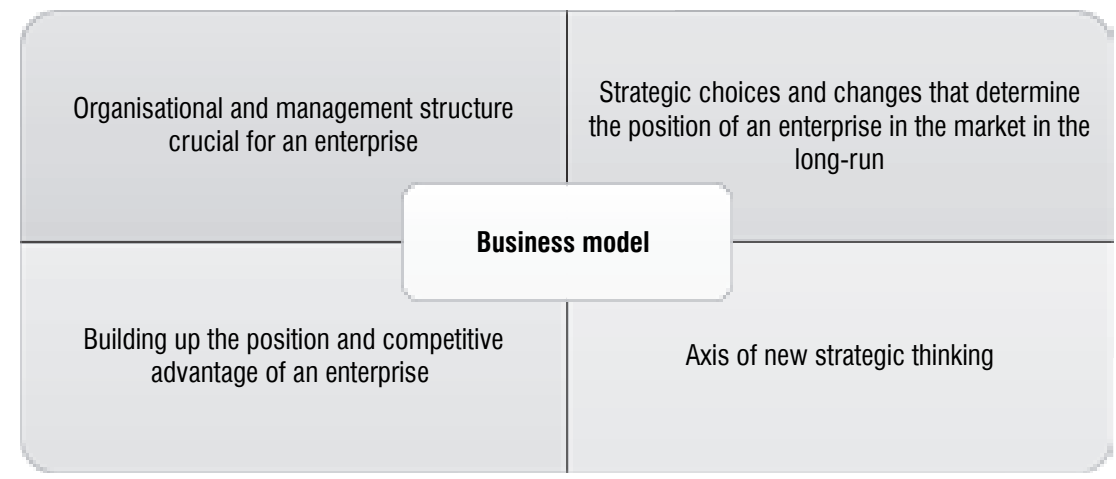

Source: Own compilation based on: Model biznesu. Nowe myślenie strategiczne, M. Duczkowska-Piasecka, M. Poniatowska-Jaksch, K. Duczkowska-Małysz (Eds.), Difin, Warszawa 2013, p. 16.

As argued by the representatives of the resource-based approach, the business model concept is deeply rooted in the resource-based view developed in management and each of its elements is understood as resource [Osterwalder et al., 2005, p. 10]. These resources are conceptual and immaterial. According to S. Cyfert and K. Krzakiewicz, a business model helps us identify the logic of links amongst resources within an organisation and activities that generate value for the company's stakeholders [Cyfert, Krzakiewicz, 2011, pp. 100-105]. A business model is a specific configuration of key resources and skills within an enterprise, which is protected from being replicated by its competitors. Besides, there is some friction (reactions) between the elements of the model, which generates value to final customers. In the systemic approach, it is a configuration of internal components of an enterprise and factors emerging from interactions with the environment modified adequately to the opportunities offered by the business environment.

A business model is a specific embodiment of management logic, which allows an undertaking to capture market opportunities, reduce risk, and identify the necessary combination of resources to generate value to stakeholders as an ultimate goal. A business model combines a vision of an enterprise and its operations and, by explaining why the undertaking in question is profitable and valuable, it is linked with strategy but not burdened with the "how" question. The latter is answered by strategic planning.

An example of a relationship between strategy and business model has been described by R. Casadesus-Masanell and J.E. Ricart [Casadesus-Masanell, Ricart, 2010]. In this case a business model covers the organisation of business activities of an enterprise and the way how stakeholder value is created, while strategy refers to choosing the business model, which helps the enterprise compete effectively. In this approach, the strategy takes precedence over the business model. On the other hand, Ch. Zott and R. Amit [Zott, Amit, 2010] believe that 
the two notions differ since strategy focuses on attaining a competitive advantage, while the model - whose centre of interest is consumer value - on generating and capturing stakeholder value. There are also C.M. DaSilva and P. Trkman who, motivated by two reasons, make a distinction between strategy and a model. Firstly, strategy is future-oriented and it is decisive for the development of skills, which, in turn, may change the business model in the future [Da Silva, Trkman, 2004, pp. 379-389]. A model describes what an enterprise is in a given moment of time. Consistently, strategy impacts the business model. S. Gregorczyk argues that a business model describes conditions for attaining a competitive advantage at a present moment, while competition strategy delineates directions and ways of generating competitive advantage over a long-time horizon. Hence, a business model answers the question "what an enterprise is doing currently to efficiently generate and capture value" [Gregorczyk, 2015, p. 90].

Operationalization of the model and its constituents are vital for how it is used in the business practice of small and medium-sized enterprises. Conceptualisation of the business model idea consists in explaining the term as a component of the competition strategy focused on how a product (service) is delivered to a selected market segment built on the existing theory of strategic management. The term "business model" is linked with the value chain introduced by Porter [Porter, 1985] and extended by Stabell and Fjeldstad, who proposed a value network [Stabell, Fjeldstad, 1998]. Within a value network an enterprise organises and enables a comprehensive set of exchange processes among stakeholders, people, and organisations. Instead of flowing sequentially from production to marketing, as is the case for a traditional chain, these goods may simultaneously and continuously enter into interactions. Teece defines a business model as an architecture chosen by an enterprise to create value and growth mechanisms [Teece, 2010, p. 172]. Architecture is the key word understood in this case as a structure, a set of relations among elements of the system, which can have a specific direction (are the relations sequential or reciprocally dependent?), power and content (information).

A. Osterwalder and Y. Pigneur proposed a comprehensive and schematic definition of a business model, which describes the circumstances in which an enterprise creates value and makes profit [Osterwalder, Pigneur, 2012]. Their proposal includes nine elements: target customers, value proposition, communication, distribution, and sales channels, customer relationship, key resources, key processes, strategic partners, revenue stream, and cost structure. These elements cover four key areas of business activity: customers, offer, infrastructure, and finance. The Osterwalder and Pigneur scheme illustrates how the value of an organisation is created through sequential managing of innovation that targets a particular market group based on a specific combination of resources and under given financial circumstances.

An outline of the Osterwalder and Pignuer business model can be enriched with other essential elements (see Figure 2), such as, inter alia, data-based management, team work, customer orientation and continuous improvement.

Customer orientation means a business seeks to anticipate future customer needs rather than being busy exclusively with creating value through meeting their current needs. Management should be exercised based on comprehensive and objective data and facts. Team work 
is another important element of the system, which is highlighted because it deploys creativity and motivates to action. The last element is continuous improvement, meaning striving for perfection by using the Deming plan-do-check-act cycle. The first element is about activity planning, focusing on what does not work and proposing ideas that may resolve the problem. Next in the cycle there is execution consisting of an experiment that is checked and, if successful, followed by action, that is implementation of changes, dissemination of results and conclusions.

Figure 2. Comprehensive business model blueprint (business model blueprint 2.0)

\begin{tabular}{|c|c|c|c|c|c|c|c|}
\hline $\begin{array}{l}\text { Data-based } \\
\text { management }\end{array}$ & \multirow{3}{*}{ 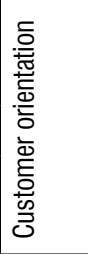 } & \multirow[t]{3}{*}{ Key partners } & \multicolumn{2}{|c|}{ Key activities } & Value proposition & Customer relationship & \multirow[t]{3}{*}{$\begin{array}{l}\text { Customer } \\
\text { segment }\end{array}$} \\
\hline \multirow[t]{2}{*}{ Team work } & & & \multicolumn{2}{|c|}{ Key resources } & Problem identification & \multirow{2}{*}{$\begin{array}{l}\text { Distribution channels and } \\
\text { communication }\end{array}$} & \\
\hline & & & $\begin{array}{l}\frac{0}{\circ} \\
\frac{0}{\alpha}\end{array}$ & $\begin{array}{l}\bar{\Phi} \\
\frac{ \pm}{ \pm}\end{array}$ & Problem resolution & & \\
\hline \multicolumn{2}{|c|}{$\begin{array}{l}\text { Continuous improvement } \\
\text { (Deming cycle) }\end{array}$} & \multicolumn{3}{|l|}{ Cost structure } & \multicolumn{3}{|l|}{ Revenue stream } \\
\hline
\end{tabular}

Source: Own compilation based on dispersed sources.

The capability of creating value is a crucial attribute of any business model that conditions a firm's competitiveness and efficiency, as well as its ability to capture market value. Business model dynamics - i.e., the ability to reconfigure and change the elements of the model depending on external circumstances and processes that are taking place around it - is another important factor.

Interesting and helpful elements of the development of a business model have been proposed by H. Chesbrough and R.S. Rosenbloom [Chesbrough, Rosenbloom, 2002]:

1. articulate the value proposed to final users - a particular function, product, application, place of offering or properties;

2. identify a target group and the market segment;

3. define the structure of the value chain of the offering;

4. estimate the cost structure and profit of producing the offering;

5. identify the position of an enterprise within the value chain linking firms from the closest neighbourhood of an enterprise plus relations taking place in it;

6. describe competition strategy.

\section{Determinants and conditions of choosing a business model for small and medium-sized enterprises}

At the organisational level, strategic management in a small enterprise is typically little formalised when it comes to strategic operations, spontaneous, irregular and selective 
in using strategic management methods and tools. While growing, an enterprise formalises its strategy-related efforts, implements increasingly more comprehensive management tools and replaces incidentiality with planning, organisation and procedures.

How a business model is formulated depends mainly on factors such as: globalisation of the economy, social changes, competitors' behaviour, IT technologies and tendencies to overcome sectoral borders.

Globalisation influences the way business models evolve since it propagates identical social and economic developments across the globe, which provides a new quality framework for business operations by creating new contextual setups. These developments are accompanied by social transformations, in particular, lifestyle changes, a higher labour force participation rate for women and ageing societies. All these factors make customers increasingly more demanding and their purchase choices are made to meet individual needs. Highly aware consumers change the pattern of purchase transactions in companies, which want to create favourable conditions for building relationships with their clients. Enterprises must differentiate their offers to meet the needs of individual clients by segmenting their preferences; as a result of the transformation in consumption new needs are created. Relations between enterprises and their customers also go through changes. Sporadic contacts become lasting relations by using interactive communication with consumers in accordance with the behavioural model of conduct, where a client transforms into an active participant of the process. Such a consumer can be referred to as a "prosumer" [Domańska, 2009], a person with deep knowledge about the market, products and services. A prosumer shares his/her knowledge and expertise and becomes a partner in business.

In terms of competition, processes currently focus on two levels: competing for customers and resources. Competing for capital and increasing investors' pressure are becoming more and more important. That has led to the value-based management concept, which consists in managing a company to increase a firm's value and directs attention to continuous improvement of performance of a business organisation.

New information technologies trigger changes in how businesses compete and improve the competitive position of a company. The global digital network has deeply transformed the business environment and market dependencies by reducing information asymmetry. As a result, there is a wide offer of products/services in the global market that has become available almost instantly. These processes opened up new areas for developing advanced business models and future implications that help create new customer needs. They also help enterprises expand their area of activity through trans-sectoral and geographic expansion that improves their competitive position and implies modifications in the corporate operational pattern and, by the same token, in business models applied in the SME sector.

Business models should be analysed in an integrated way because they are holistic by nature. Amongst the determinants of choosing a business model we should bear in mind the multiplicity of types of enterprises and business activity sectors that compete at different levels as well as increasingly more enterprises and markets that are going virtual (see Figure 3). 
Figure 3. Determinants of business model choice and implementation

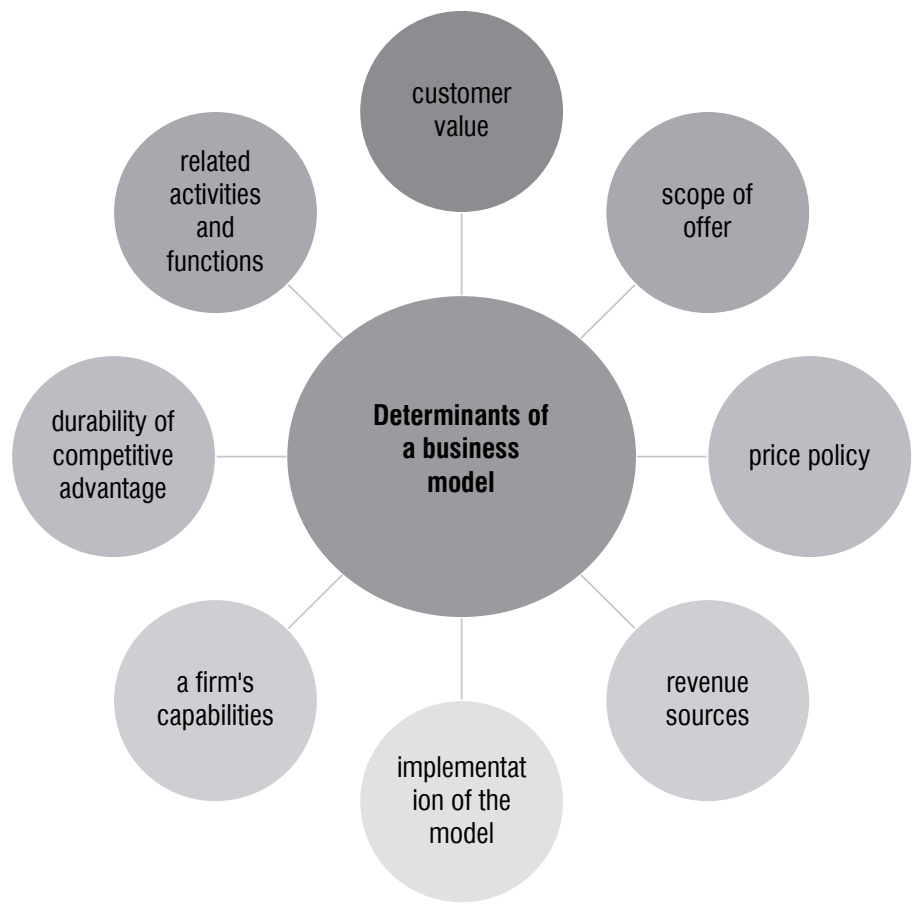

Source: Own compilation based on A. Afuah, C.L. Tucci, Internet Business Models and Strategies, [Polish edition] Oficyna Ekonomiczna, Kraków 2003, p. 86.

The determinants of successful application of a business model belong to the following three areas:

- needs and values represented by stakeholders and the external environment;

- a firm's offer: its products, services, ways in which they are offered;

- external factors: organisational structure, resources, knowledge, skills, key competences.

Strategic circumstances of a business model include the following factors: competitive position, an enterprise's mission, operational abilities to generate value and profit, comprehensiveness, process safety, and value leadership.

Importantly, business models are used in small and medium-sized enterprises to enable capturing parts of the income from the value delivered to customers. Business model concepts highlight its two principal dimensions. The first focuses on how customer value is created and delivered [Chesbrough, Rosenbloom, 2002]. The other relevant dimension is that of capturing value for an enterprise [Amit, Zott, 2001] as it generates income and increases the value of a business organisation.

Operationalization of a business model focuses on how it is implemented into the business practice for reasons pertaining to seeking the profitability of the model and its capability to increase flexibility. In this case operational activities get subordinated to the attainment of planned effects that determine the delivery of corporate goals. A business model is a configuration of material and immaterial resources that provide a platform for creating and 
offering value to customers and triggering an adequate logic of income creation. Increasing the efficiency of a business model means we can configure it to achieve the maximum rate of return [Jabłoński, 2015, p. 103].

A business model should be adaptable to evolving customer needs and preferences. When using a business model, we should be able to generate innovative solutions for the company and for its customers at each stage of the value chain; the same is true of minimising costs by using a business model, permanent risk reduction, and building lasting relations with customers.

Profit potential determined by process efficiency, unique offer, internal coherence of the organisation, and an ability to create profit is also an important building block of a business model.

\section{Summary}

In a turbulent environment small and medium-sized enterprises, which sufficiently well in advance design and implement an adequate business model will be able to find solutions to build competitive advantage and create value. Changes in the environment take place so rapidly that they force managers to permanently adjust business models and changes should be introduced timely.

A business model is a specific bridge between strategy and resources which links competences, resources, processes and management methods. Three main building blocks of the model include: competitive advantage, resources, and value chain. Success of enterprises, mainly SMEs, in the modern world is not conditioned by access to technology or its use or the offer but by the use of an appropriate business model. The future of SME innovation lies in the business model. Success depends on offering unique value in a specific market.

Summing up, a business model is based on key elements: strategy, necessary resources, stakeholder relationships, and value creation, which are interlinked and form configurations [Hamel, 2002 pp. 73-74]. A business model is subject to continuous verification and it must be adjusted to changes in its market environment. We must bear in mind that an optimum configuration of a business model should be based on innovation, which may produce higher profitability of a business organisation. That allows generating profit from the created value.

Because of the complexity of the term and growing population of small and medium-sized enterprises, this paper makes a contribution into further, more in-depth studies and analyses devoted to choices, implementation and improvements of business models in SMEs. 


\section{References}

1. Afuah A., Tucci C.L., 2003. Internet Business Models and Strategies, [Polish edition]. Kraków: Oficyna Ekonomiczna.

2. Amit R., Zott C., 2001. Value creation in e-business. Strategic Manage Journal, No. 22.

3. Boulton R., Libert B., Samek S., 2000. Cracking the Value Code. Arthur Andersen. USA: Harper Colinns.

4. Casadesus-Masanell R., Ricart J.E., 2010. From strategy to business models and onto tactics. Long Range Planning, No. 43.

5. Chesbrough H., Rosenbloom R.S., 2002. The role of the business model in capturing value from innovation: evidence from Xerox Corporation's technology spin off companies. Industrial Corp Change, No. 11(3).

6. DaSilva C.M., Trkman P., 2004. Business model: what it is and what it is not. Long Range Planning, No. 47.

7. Domańska K., 2009. Kim jest prosument. Marketing w praktyce, No. 2.

8. Falencikowski T., Nogalski B., 2011. Model biznesu w perspektywie zasobowej, rozwój szkoły zasobowej zarządzania strategicznego. w: Rozwój szkoły zasobowej zarządzania strategicznego, red. R. Krupski, Prace Naukowe Wałbrzyskiej Wyższej Szkoły Zarządzania i Przedsiębiorczości, Wyd. WWSZiP, Wałbrzych

9. Hamel G., 2002. Leading the revolution. Watertown: Harvard Business School Press.

10. Jabłoński A., 2015. Skalowalność modeli biznesu w środowisku sieciowym. Warszawa: Difin.

11. Model biznesu. Nowe myślenie strategiczne, 2013. M. Duczkowska-Piasecka, M. Poniatowska-Jaksch, K. Duczkowska-Małysz (Eds.). Warszawa: Difin.

12. Modele biznesu w handlu detalicznym, 2010. M. Sławińska (Ed.). Poznań: Wydawnictwo Uniwersytetu Ekonomicznego w Poznaniu.

13. Osterwalder A., Pigneur Y., Tucci C.L., 2005. Clarifying Business Models: Origins Present and Future of the Concept. Communication of the Association from Information Systems, Vol. 15.

14. Osterwalder A., Pigneur Y., 2012. Tworzenie modeli biznesowych, podręcznik wizjonera., Gliwice: Helion.

15. Porter M.E., 1985. Competitive Advantage: Creating and Sustaining Superior Performance. New York: Free Press.

16. Przedsiębiorstwo odporne na kryzys, 2015. M. Romanowska, W. Mierzejewska (Eds.). Warszawa: Oficyna Wolters Kluwer business.

17. Rozwój szkoły zasobowej zarządzania strategicznego, 2011. R. Krupski (Ed.). Prace Naukowe Wałbrzyskiej Wyższej Szkoły Zarządzania i Przedsiębiorczości, Wałbrzych

18. Stabell C.B., Fjeldstad O., 1998. Configuring Value for Competitive Advantage: On Chains, Shops and Networks. Strategic Management Journal, 19(5).

19. Teece D.J., 2010. Business Models, Business Strategy and Innovation. Long Range Planning., 43.

20. Zott Ch., Amit R., 2010. Business model design: An activity system perspective. Long Range Planning, No. 43. 
